\title{
Surface coal mine permit application for successful reclamation, semi-arid shortgrass prairie (Wyoming, USA)
}

\author{
Anna Krzyszowska Waitkus ${ }^{1}$
}

Received: 5 July 2017/ Accepted: 13 November 2017/Published online: 27 November 2017

(C) The Author(s) 2017. This article is an open access publication

\begin{abstract}
Approximately 40\% of USA coal originates in an ecologically sensitive area of semi-arid shortgrass prairie in Wyoming. Before a surface coal mine can begin operation in the USA, it must secure a mining permit and comply with regulations and performance standards under the USA Surface Mining Control and Reclamation Act (SMCRA), other federal environmental acts, and state programs. The Wyoming Department of Environmental Quality (WDEQ)/Land Quality Division (LQD) administers Wyoming's coal regulatory program. The permit application and bonding process for the largest surface coal mine permit in the USA, North Antelope Rochelle Mine (NARM) located in short grassland prairie in the northeast Wyoming, is discussed. The permit application process begins with the collection of baseline environmental data that characterizes premining conditions of the permit area. The permit application includes adjudication information, baseline information, mine and operation plans, and reclamation plans. Fulfillment of permit commitments and requirements of rules and regulations are inspected monthly by the LQD's representative in the field. Before a mine permit is issued, the mine operator must submit a reclamation bond to secure the performance of reclamation obligations that is later revised annually. In Wyoming, four reclamation bond release phases indicate the completion of various stages of the reclamatikon process. NARM's specific bond release verification cirteria, performance standards, and field verificatoins of bond release phases are discussed. The Bond Release Geodatabase (a GIS/GPS approach) was developed for this mine to monitor progress in meeting criteria and performance standards for incremental bond release. The Bond Release Geodatabase significantly reduces the time needed to track bond release progress, reach agreement between operator and regulator, and improve the state inspector's ability to assess reclamation adequacy and progress.
\end{abstract}

Keywords Surface coal mine permitting - Bonding - Reclamation - GIS/GPS geodatabase - USA rules and regulations · Inspections

\section{Introduction}

The State of Wyoming produces approximately $40 \%$ of all mined coal in the USA (Carroll 2011). The Land Quality Division (LQD) of the Wyoming Department of

The 2nd International Symposium on Land Reclamation and Ecological Restoration, October 20-23, 2017, Xi'an, China.

Anna Krzyszowska Waitkus

enviro@wyoming.com

1 Environmental Consulting, 80 Eagle Nest, Laramie, WY 82070, USA
Environmental Quality (WDEQ) is in charge of Wyoming's coal regulatory program (State of Wyoming 2016). The state's regulations and environmental protection performance standards are important in achieving successful reclamation results. According to WDEQ/LQD Coal Rules and Regulations (Wyoming State Rules and Regulations 2017), the goal of surface coal mine reclamation is to restore the land to its pre-disturbance ecological function. To accomplish this goal, a thorough baseline inventory of environmental conditions must be performed prior to mining (Norton et al. 2010). It is especially important in the semi-arid environment of Wyoming, where a native vegetation of the shortgrass prairie is sensitive to any 
disturbance due to the lack of the rainfall (Knight et al. 2014). The baseline inventory includes surveys and assessments of: cultural and historical resources; soils; vegetation; wildlife, surface and groundwater hydrology; climatology; wetlands, and geological data (soil and rock structure, coal seam thickness). The company then develops mining and reclamation plans incorporating all of the environmental components of the baseline inventory.

Before a company can begin mining in the USA, it must secure a mining permit and comply with regulations and performance standards of the USA Federal Surface Mining Control and Reclamation Act (SMCRA) of 1977 (Public Law 95-87, referred to as SMCRA), state programs and other federal environmental acts (USA Government Publishing Office 2016). Verification of state rules and regulations, permit commitments, and performance standards are conducted through field inspections, annual reports, and permit revisions.

Few references discuss surface coal mine permit content and its role in achieving reclamation goals (USA Congress, Office of Technology Assessment 1986). Specific studies conducted in the western USA states discuss the effects of mining and reclamation approaches on geomorphic processes (Toy and Black 2000), soil properties, and management (Pinchak et al. 1985; Schroeder and Vinning 1993; Buchanan et al. 2005; Reynolds and Reddy 2012), and re-vegetation strategies and methods (Williams et al. 2002; Schuman et al. 2005; Strom et al. 2010).

Before a mine permit is issued, the mine operator must submit a reclamation bond to secure the performance of reclamation obligations (Bonogofsky et al. 2015). The operator might reduce a reclamation bond by reclaiming disturbed areas simultaneously with mining coal. Reclamation progress in Wyoming occurs in four phases of bond release together with the verification of bond release criteria and performance standards (Krzyszowska Waitkus and Blake 2011).

This paper discusses the permit content information and the bond release processes of the largest surface coal mine permit in the USA, the North Antelope Rochelle Mine (NARM), located in the semi-arid (less than $300 \mathrm{~mm}$ rain/ year) shortgrass prairie of northeast Wyoming. Information presented in this article were obtained from the Permit 569-T8 Peabody Powder River Mining LLC North Antelope Rochelle Mine stored in the Cheyenne office of the WDEQ/LQD (Permit 569-T8 2014).

NARM is an active open pit mine that produced over 111 million tons of coal in 2015. The permit area covered 18590 ha in 2015. Since the initial operation began in 1982, approximately 7680 ha have been disturbed. Coal seam thickness averages approximately $20 \mathrm{~m}$ with an average overburden thickness approaching $90 \mathrm{~m}$. The mine contains three major pits: East Pit (6 km long), North Pit
(8 km long), and West Pit (6 km long). The mine uses three operating draglines and 11 shovels supported by numerous trucks and bulldozers.

\section{Rules and regulations}

Since 1969 the state of Wyoming has created numerous environmental acts to help regulate the mining industry. They were revised after the primary federal law SMCRA was enacted in 1977, creating a basis for environmental laws, rules and regulations in various states (Squillace 1990). SMCRA established minimum federal standards for the regulation of mining, introduced an idea of bonding, and provided penalties for violations of the laws, regulations, or permit conditions. A federal agency, the Office of Surface Mining, Reclamation and Enforcement (OSMRE), was created to oversee SMCRA and revise it on an ongoing basis. The Code of Federal Regulations lists the rules and maintains an up-to-date electronic version (USA Government Publishing Office 2016).

In addition to SMCRA, mining operations must abide by regulations put forth by a number of other federal and state environmental agencies. In Wyoming these include: USA Office of Surface Mining, Reclamation and Enforcement; USA Army Corps of Engineers; USA Environmental Protection Agency; USA Fish and Wildlife Service; Wyoming Game and Fish Department; and WDEQ.

SMCRA's major components were incorporated into the Wyoming Environmental Quality Act and Industrial Development Information and Siting Act (State of Wyoming 2016) giving WDEQ/LQD the authority to establish standards for reclamation. These standards allowed for the creation of rules and regulations for the coal industry in Wyoming (Wyoming State Rules and Regulations 2017), which became an official part of Wyoming's coal regulatory program after approval by the USA Secretary of the Interior. Rules quoted in this article are from the Wyoming Environmental Quality Act and Industrial Development Information and Siting Act (State of Wyoming 2016) and from WDEQ/LQD Coal Rules and Regulations (Wyoming State Rules and Regulations 2017) that are constantly being updated to reflect changes in SMCRA. All these rules, regulations, and guidelines can be found on the website of the WDEQ/LQD.

\section{Content of the permit}

Information presented in the permit follows federal and state rules and regulations and contains specific permit commitments. Surface coal mining permits are issued for a term not to exceed 5 years, after which the operator must 
request and submit a revised permit for a term renewal. A surface coal mining permit must be terminated if the permittee has not commenced surface coal mining operations covered by the permit within 3 years of permit issuance.

The NARM's coal mine permit application consists of four major portions: adjudication Section (2 volumes), supporting data-baseline information (18 volumes), mine plan including mining method, schedule, and mining hydrology (7 volumes), and reclamation plan describing processes of overburden and topsoil handling with a reclamation schedule in the form of numerous maps (2 volumes). More than $60 \%$ of the information concerns premining baseline data.

The application, once approved, constitutes the enforcement contractual document (permit) with the WDEQ/LQD that is used during compliance inspections of mining operations. Any discrepancy from the permit commitment found during an inspection or through a revision of an annual report could result in a violation with associated penalties. The permit must contain a time schedule to address the following: mining progression (topsoil removal, overburden removal, coal removal), backfilling, grading, contouring, and seeding. The time schedule uses yearly blocks for 5 years followed by blocks of 5 year periods until the end of mining. Maps and crosssections included in the permit must follow specific, consistent requirements related to scale, contours, legend, etc. All engineering maps, plans, and designs or reports including cross sections must be certified by a professional engineer registered under the laws of the State of Wyoming (2016). All mining and reclamation maps are presented in the same scale of $1: 1500$.

\subsection{Adjudication information}

Adjudication files include forms showing the surface land to be affected by the mine, the license to mine coal, a certificate of public liability insurance, a list of surface and coal owners, documentation of surface owner consent and right of entry, the permit area boundary, and lands to be affected over the life of the mine. New permit applications must contain the reclamation performance bond estimate, covering all disturbances and construction anticipated during the first 12 months of the permitted operation (State of Wyoming 2016). This bond amount is updated annually by the operator through annual reports and approved by the WDEQ/LQD according to WDEQ/LQD Guideline No. 12 (Wyoming Department of Environmental Quality 2017).

A certificate of public liability insurance must be submitted with the permit according to requirements of the State of Wyoming (2016). An appendix of lands within and adjacent (within $0.8 \mathrm{~km}$ ) to the permit area contains a list of surface owners and coal rights, and records of water rights owners. Surface ownership includes private, federal (e.g., USA Department of Agriculture), and state of Wyoming lands.

\subsection{Baseline information}

Pre-disturbance inventory is a critical part of reclamation planning and establishes a framework and schedule for successful restoration of severely disturbed land, monitoring, and evaluation (Norton et al. 2010). According to rules and regulations the following information is required in the baseline information of the permit: land use, brief history of the area including description of historic places, archeological and paleontological resources, climatology, topography, geology and overburden assessment, hydrology (groundwater, surface water, water rights), soil assessment, vegetation inventory, and wildlife use (State of Wyoming 2016; Wyoming State Rules and Regulations 2017).

The premining land use summary is delineated on a map, statistically calculated, and presented in a table. For example, the categories of land use within the permit area include: surface coal mining, grazing, oil and gas development, wildlife habitat, and recreational uses. The permit contains the hectares of each land use category including a vegetation type.

Historical overview, cultural resource sites, and paleontological inventories are conducted on all permit areas according to requirements included in the Wyoming Environmental Quality Act. The individual inventory, evaluation, and mitigation reports are compiled in proprietary volumes to protect the confidentiality of cultural resources under the Archeological Resources Protection Act of 1979 (State of Wyoming 2016). The characteristics of climatology presented in the permit include temperature, growing season, precipitation, humidity and evapotranspiration, and winds. Due to the potential for the air pollution from dust, the operator must present air quality monitoring plans including the locations of air quality monitoring stations.

The topography, geology, and overburden assessments describe the premining topography, geology, stratigraphy, quality and quantity of premining overburden (State of Wyoming 2016). Geologic cross sections provide information on the lithology across the permit area including overburden, interburden, and coal thickness. Wyoming mines must follow the requirements of an Approximate Original Contour (AOC) type topography where surface configuration achieved by backfilling and grading of mined areas must closely resemble the general surface configuration of the land prior to mining and complement the drainage patterns of the surrounding terrain (Wyoming State Rules and Regulations 2017). The State of Wyoming 
and other states (Montana, Colorado, New Mexico, and North Dakota) require the establishment of AOC as per federal regulations unless specifically exempted due to excess or lack of overburden material.

During the mining and reclamation process two sampling programs are employed at NARM to define unsuitable overburden material ahead-of-mining and backfill material. In order to define unsuitable overburden material ahead-of-mining, overburden sampling procedures are established for material moved by a truck/shovel operation only. In NARM, at least one hole per 64 ha within the permit area is sampled for chemical analysis. Sample cuttings are collected on intervals at a maximum of $3 \mathrm{~m}$ in specific lifts of $16.5 \mathrm{~m}$ to a depth of $148 \mathrm{~m}$. Samples are analyzed for quality by comparing with parameters and concentrations described in WDEQ/LQD Guideline 1 (Wyoming Department of Environmental Quality 2017). The location of unsuitable material collected from the baseline study is delineated on a map titled "Overburden Suitability" included in the permit and also is shown on the Geographic Position System (GPS) unit located on a shovel removing overburden. The map on the GPS of the shovel delineates places where these unsuitable materials could be stored (at least under $1.2 \mathrm{~m}$ of suitable material) and cannot be stored (such as in close proximity to a drainage channel or its flood plain).

Postmining backfill quality procedures include a description of the sampling methods, suitability classification, and selective placement. Composite samples of backfill material are collected at depths of $0-0.6 \mathrm{~m}$ and $0.6-1.2 \mathrm{~m}$ and analyzed for quality by comparing with parameters and concentrations described in WDEQ/LQD Guideline No. 1. Each sample site is located on $150 \mathrm{~m}$ centers ( 2 ha). If unsuitable material is found in the top $1.2 \mathrm{~m}$ of regraded spoil material, a mitigation plan is implemented to verify the quality of the initial backfill sample or to more accurately define the area of unsuitability within the initial sample area. The unsuitable backfill material is capped or removed and relocated deeper under at least $1.2 \mathrm{~m}$ of suitable material (excluding areas under floodplain channel bottom of reclaim drainages). Chemical properties of backfill material with a map showing the collection sites are submitted with the annual reports. Results are analyzed by the operator and reviewed by the LQD specialist. Best management practices concerning successful revegetation and chemical properties of surface material show a direct connection between the chemical results of the overburden baseline study and the practical implementation of burying unsuitable overburden and backfill material.

Premining hydrology and hydraulics for both surface and ground waters within the permit area and $0.8 \mathrm{~km}$ adjacent area around the permit are discussed in the baseline study (State of Wyoming 2016; Wyoming State Rules and Regulations 2017). Surface water includes rivers, creeks, lakes, and reservoirs within and adjacent to the permit area. Descriptions of premining stream characteristics (drainage density, channel sinuosity, stream channel morphology) are discussed, along with drainage basins and surface water runoff quantity and quality. At NARM, baseline water quality data for major streams are collected regularly and analyzed for specific parameters (e.g. ammonia, nitrogen, nitrate, bicarbonate, boron, carbonate, fluoride, sulfate, total dissolved solids, and dissolved arsenic, calcium, chloride, chromium, iron, molybdenum, potassium, sodium, and zinc). Information is presented on aquifers that may be affected, their areal extent and hydraulic properties, groundwater quality, and groundwater recharge and discharge areas. In 2016, NARM 93 groundwater monitoring sites and seven surface water stations were sampled regularly according to the permit commitments.

Soil at the mine is ranked as suitable or unsuitable for salvage according to chemical or physical criteria that affect revegetation success. These criteria are established by the state regulatory authority and reflect characteristics of climate and vegetation (USA Congress, Office of Technology Assessment 1986). All suitable soils must be salvaged and replaced on the reclaimed area. Most prairie soils in Wyoming are thin with low organic carbon content. It was estimated that minimum concentration of $0.52 \%$ organic content or $0.89 \%$ organic matter is necessary to sustain an adequate level of nutrient cycling in Wyoming reclaimed soils (Ingram et al. 2005).

WDEQ/LQD Guideline No. 1A (Wyoming Department of Environmental Quality 2017) includes criteria for suitability for soils or soil substitutes. Soil assessment requirements include a site specific soil inventory and suitability maps with tabulations of soil salvage depths for affected lands (State of Wyoming 2016). At least one sample for each soil series in the affected area is collected and analyzed for specific elements (e.g. pH, conductivity, particle size, texture, sodium absorption ratio, selenium, boron, and organic matter). Results are compared with the criteria to determine soil suitability. The results of quantitative soil analyses are used to create a soil stripping depth map for affected lands. A table in NARM's permit lists the following for each soil mapping unit: area units where soil removal is planned, average depth of soil to be removed, and volumes of soil to be salvaged. NARM's permit includes a map showing various soil unit descriptions with soil salvage depths. This information assists in determining soil depth application during the reclamation process.

Vegetation inventory requirements include delineation, mapping and tabulation of major vegetation communities, 
cover sampling of vegetation communities, species lists, shrub density determinations, and tree counts. The vegetation inventory also includes the selection of a reference area located outside of a disturbed area. Data from a reference area is used to compare data from the reclaimed and revegetated areas. NARM's permit includes a map titled "Native Vegetation Types" delineating eight major vegetation communities.

The baseline study includes a description of potential and actual faunal distribution within the permit and areas adjacent to the permit with a list of indigenous vertebrate wildlife species. Wildlife studies are done in accordance with state and federal wildlife agency requirements. NARM's permit includes a map titled "Wildlife Features", showing prairie dog colonies, intact raptor nests, former raptor nests, nesting platforms, and active and inactive sage grouse leks.

\subsection{Mine plan}

According to State of Wyoming requirements, the mine plan must include a description of type and method of mining, life of the mine in years, affected area units, estimated annual production, mine facilities, blasting plan, equipment list, and mining hydrology. The permit application must contain a map showing the estimated order and progression of mining and reclamation on all proposed affected lands (Wyoming State Rules and Regulations 2017). Mine sequence maps for soil, coal removal, and rough backfilling include identification of the area to be mined during the first 5 years in 1-year blocks during the specific term and in 5-year blocks for the remaining life of the mine. Soil salvage and handling techniques as well as erosion control plans are presented in the mine plan section. Tables of soil volumes that will be salvaged, material excavated and backfilled, and hectares of areas stripped of soil and graded with soil replaced and seeded are presented for each of the first 5 years, and in 5-year blocks thereafter, until the end of mining. This information is included in NARM's permit table titled "Material Handling Summary." The information is verified during annual report reviews and inspections to ensure the operator is following permit commitments and reclamation is occurring according to the schedule. The operator demonstrates the ability to achieve AOC through the calculation of bulking factors (swell factors) and estimation of overburden material volume available for backfilling.

The mine plan must ensure the protection of the quantity and quality of, and rights to, surface water and groundwater both within and adjacent to the permit area (Wyoming State Rules and Regulations 2017). Mining hydrology sections include a plan and timetable for control and treatment of surface and groundwater, discussion, and determination of probable hydrologic consequences within and outside the permit area for the duration of mining. The plan must estimate groundwater drawdown and provide a monitoring plan to include the collection, recording, and reporting of data on water levels and quality.

A hydrologic control plan for surface water includes a hydrologic control map, structure designs, and a maintenance plan. Six of the 29 volumes of NARM's permit application contain engineering plans of sedimentation reservoirs, highwall sumps, and permanent impoundments. Design requirements for each constructed feature of the surface water control plan follow WDEQ/LQD Guideline No. 8 (Wyoming Department of Environmental Quality 2017) and Coal Rules and Regulations (Wyoming State Rules and Regulations 2017).

\subsection{Reclamation plan}

The reclamation plan describes procedures and methods used to minimize adverse impacts during mining and to restore disturbed land to premining land use (Norton et al. 2009). By definition, reclamation "shall restore the land to a condition equal to or greater than the highest previous use." The land, after reclamation, must be suitable for the previous use or must have a use which is of greater economic or social value than previous uses (Wyoming State Rules and Regulations 2017). At NARM, reclamation must restore the land to livestock grazing and wildlife use functions. The reclamation plan coordinates with the mining plan and contains a time schedule to complete reclamation as quickly as possible.

NARM's reclamation plan includes information on soil removal, storage, protection, and replacement, along with a plan for backfilling, grading, and contouring of affected lands. Also included are methods of monitoring hydrologic restoration of disturbed land, revegetation plans with a means of measuring of success, and information on postmining land use.

Reclamation begins with the salvage and protection of soil from the disturbed land. Salvaged soil is either stockpiled and protected from erosion and degradation or placed directly on regraded areas (direct haul). According to NARM's experience, direct haul produced the best revegetation results. Direct haul can result in higher mycorrhizae levels, better physical characteristics, and a slightly greater potential for seed bank benefit as compared to stockpiled soil (Schuman 2002; Anderson et al. 2008). However, caution should be taken if soil contains infestations of weeds or other undesirable species. The soil replacement management plan in NARM's permit discusses erosion control and water conservation practices, soil replacement depth range, and soil characteristics for the restoration of critical and important habitat such as 
wetlands, floodplains etc. Soil is usually applied at a uniform depth on regraded areas in Wyoming surface coal mines. According to the Wyoming State Rules and Regulations (2017), variable soil depths are also allowable: "Soil thickness may also be varied to the extent such variations help meet the specific revegetation goals identified in the permit." Some studies performed in the western USA showed that revegetation results can be affected by varying soil depths (Buchanan et al. 2005; Bowen et al. 2005; Williams et al. 2002). To enhance the growth of hard-to-establish shrubs such as big sagebrush (Artemisia tridentata), NARM has developed two soil replacement depth ranges: typical $(15-40 \mathrm{~cm})$ and deep $(40-120 \mathrm{~cm})$.

Soil is applied on backfilled and graded areas as soon as possible following mining, according to performance standards (Chapter 4, Section 2(b)) of the Wyoming State Rules and Regulations (2017):

- "Rough backfilling and grading shall follow coal removal as contemporaneously as possible based upon the mining conditions. The operator shall include within the application for a permit to mine a proposed schedule for backfilling and grading with supporting analysis."

- "Backfilled materials shall be replaced in a manner which minimizes water pollution on and off the site and supports the approved postmining land use. Preparation of final graded surfaces shall be conducted in a manner that minimizes erosion and provides a surface for replacement of soil that will minimize slippage."

- "All affected lands shall be returned to their approximate original contour..."

The recontoured surface design has critical effects on postmining vegetation, land stability, and postmining land use (USA Congress, Office of Technology Assessment 1986). In Wyoming's semi-arid environment, a complex (convex on top, concave at bottom) slope of less than 25\% has been found to be least prone to erosion. To avoid long uniform slopes, constructed slope lengths do not exceed premining lengths and are shorter than $150 \mathrm{~m}$ long. No highwalls may be left unless they are approved by the Administrator of the WDEQ/LQD. During reclamation, pre- and postmining topographies are compared to determine if reclamation achieved requirements of AOC topography (Steward et al. 2006). In NARM's permit, preand postmining slope frequency and distribution are illustrated graphically (showing e.g., average slope, median slope, and slope interval). Slope distribution analysis is performed using state-of-the-art terrain modeling and analysis software. Analysis of histograms and cumulative frequency curves indicate a strong correlation between preand postmining slopes at NARM.
A rebuilt hydrologic system must be erosionally stable to drain water and blend with surrounding drainage systems. For NARM, surface water quality is predicted to be similar to premining and meet premining class of use standards. Hydrologic restoration plans for surface water discuss postmining watershed characteristics, practices to be used for drainage reconstruction (including channel geometry), locations of permanent impoundments, and a postmining monitoring plan. The function of Porcupine Creek has been restored by rebuilding the creek structure, sinuous channel, and hydrology. The restoration established a maximum amount of wetland and riparian habitat and stabilized streambanks (Hansen and Murphree 2003).

Structures (facilities and flood control reservoirs, sediment ponds, diversions, sediment traps, alternate sediment control measures) constructed in NARM's permit area control runoff and provide sediment control during mining. According to Wyoming State Rules and Regulations (2017), sediment can't leave the permit boundary and cause an off-site impact. Sediment ponds are depicted on the Mine and Reclamation Plan Map titled "Hydrologic Control Plan." Sixty-one permanent impoundments as of 2014 in NARM's permit area will supply water for livestock and wildlife, and will be used as wetland mitigation. Permanent impoundments on reclaimed surfaces are delineated on the Mine and Reclamation Plan Map titled "Post-mining Contours with Hydrologic Restoration."

Hydrologic restoration plans for groundwater describe the source of recharge and provide a postmine monitoring plan with a map of permanent backfill well locations. A discussion of probable hydrologic consequences estimates final ground and surface water quantity and quality. The assessment of ground water quantity includes rate of recovery predictions for the affected and backfill aquifers. A map showing final anticipated potentiometric surfaces of the affected aquifer is provided in NARM's permit.

The major goal of the reclamation plan is to establish stable vegetation communities on chemically suitable soil and backfill material. According to the revegetation performance standard "The operator shall establish on all affected lands a diverse, permanent vegetative cover of the same seasonal variety native to the area or a mixture of species that will support the approved postmining land use in a manner consistent with the approved reclamation plan. This cover shall be self-renewing, and capable of stabilizing the soil" (Wyoming State Rules and Regulations 2017). The revegetated area must support the approved postmining land use. NARM's revegetation plan provides a discussion on vegetation establishment methods (seed mixes, seeding techniques, mulching materials and rates, husbandry practices). Also included are interim vegetation monitoring and final revegetation success plans. Various seed mixes are developed based on baseline studies and on- 
site evaluation. Native plant species are preferred, with introduced species used only to provide utility in the mixes. The seed mixes correspond to the following vegetation types: grassland, riparian grassland, sagebrush grassland, playa grassland, shrub mosaic and sagebrush mosaics. All of these communities are native to the premining environment. High plant production on reclaimed soils in Wyoming, despite lack of fertilization, suggests that total nitrogen is not limiting production (Ingram et al. 2007). It was found that reclaimed soils in Powder River Basin in Wyoming had recovered structurally towards a native soil condition after a period of 10-15 years (Wick et al. 2009). Reclamation success is determined by a quantitative comparison of data from the reference area with data from the reclaimed area that include: cover (vegetative cover, total ground cover), production (total production, specific species production), density and distribution (shrubs, trees), species diversity, and species composition (Bilbrough and Howlin 2012). This information is presented and discussed in the NARM's annual report. Also specific areas planted in the various seed mixes, along with seeding rates, are included in tables and maps.

Disturbed areas seeded with native shrub and grass species also provide habitat for wildlife. Rock piles are constructed to simulate natural features. To reduce the effects of mining on birds of prey, several mitigation measures have been incorporated into the reclamation plan. Wildlife mitigation and monitoring plans include information on all habitat restoration procedures.

The NARM permit includes following maps (scale 1:1500) and exhibits showing major steps in the mining/ reclamation processes together with a time schedule: "Topsoil removal (disturbance) schedule"; "Hydrologic Control Plan"; "Mining schedule"; "Reclamation schedule (topsoil replacement)"; "Postmining contours with hydrologic restoration"; "Postmining contours with surface slope distribution"; "Postmining vegetation"; and "Postmining environmental monitoring locations." These maps are reviewed in the field during inspections. Also reviews of annual reports are important tools in determining if the operator is on time with the planned schedule of mining/ reclamation processes. In case of delay or change in the direction of mining and reclamation, the operator must submit a revision to the permit.

\section{Reclamation bond performance}

Before a mine permit is issued the mine operator must submit a reclamation bond to secure the performance of reclamation obligations. The cost of reclaiming the disturbed areas of a coal mine is revised and updated annually through annual reports submitted to WDEQ/LQD. A reclamation performance bond or financial assurance must be large enough to cover the full costs of reclamation to ensure that the regulatory authority will have sufficient funds to reclaim the site if the permittee fails to complete the reclamation plan or hire a third party to complete the reclamation plan in the event of a bankruptcy of the coal mine company. The bond release can begin 5 years from the date of permanent seeding in the eastern USA and 10 years after permanent seeding in the western USA.

In Wyoming, there are four bond release phases (Area Bond, Phase 1, 2, and 3) for surface coal mines indicating the completion of various reclamation phases (Krzyszowska Waitkus and Blake 2011) (Table 1). In general, performance standards related to the release of performance bonds for Area Bond and Phase 1 include the area being backfilled and regraded with a functional drainage system and applied soil. For Phase 2, vegetation cover must be established in stable areas without erosion. For Phase 3, the revegetation standards and goals must be completed (Wood and Buchanan 2000). Revegetation as a portion of the assessment of reclamation success created a lot of discussion between coal operators, regulators, and environmental specialists for long time in the state of Wyoming (Krzyszowska Waitkus et al. 2000; Schuman 2002).

The amount of the bond is revised annually through annual reports according to WDEQ/LQD Guideline 12 (Wyoming Department of Environmental Quality 2017). Bond release submittals are not part of the permit, but the bond amount and bonding instruments (e.g. letter of credit, certificates of deposit, and treasury bills) are submitted with the permit.

As a result of cooperation between the federal agency, private industry, environmental consultants, and WDEQ/ LQD representatives a set of criteria (Table 1) and performance standards was established that have to be fulfilled and verified before the reclamation bond can be released.

Table 1 Verification of bond release criteria

\begin{tabular}{ll}
\hline $\begin{array}{l}\text { Bond release } \\
\text { phase }\end{array}$ & $\begin{array}{l}\text { Verification of bond release criteria } \\
\text { Area bond }\end{array}$ \\
Phase 1 & $\begin{array}{l}\text { Backfilling, regrading completed according to } \\
\text { approved plan } \\
\text { Stream channel reconstructed and soil applied }\end{array}$ \\
Phase 2 & $\begin{array}{l}\text { Vegetation established (ocular evaluation) } \\
\text { Surficial stability established }\end{array}$ \\
& $\begin{array}{l}\text { Permanent ponds construction design approved } \\
\text { Revegetation success standards established } \\
\text { (statistical analysis) }\end{array}$ \\
& $\begin{array}{c}\text { Mitigation of wetlands (approved by the US Army } \\
\text { Corps of Engineers) }\end{array}$ \\
& Tree established
\end{tabular}


Up-to-date information (WDEQ/LQD Guidelines 20, 21, 22,23 , and 25) regarding bond release verification and compliance standards is posted on the Wyoming DEQ website (Wyoming Department of Environmental Quality 2017).

As reclamation phases are completed, the permitte may apply for incremental phased bond release. Phased bonding encourages companies to begin reclamation as soon as possible (called contemporaneous reclamation). Specific bond release requests are approved in the field after joint inspection by the land owners, permit operator, LQD, and OSMRE representatives. Additionally, the operator compares the data gathered during the baseline inventory with data gathered from the reclaimed land. After reviewing the submitted information and performing a field inspection, the LQD representative makes a decision to approve or deny the bond release request. If an Area Bond and Phase 1 request is approved, $60 \%$ of the bond can be released, for Phase 2, 15\%, and for Phase 3, 25\% of the bond can be released.

Various phases of bond release require verification of criteria and performance standards in the field which represents a challenge for the regulatory agency, especially for large mines. These challenges require a system to streamline field data collection which can be utilized in evaluating bond release and compliance requirements. As a result of these challenges, a Bond Release Geodatabase was developed for NARM in Wyoming. The system used a Geographic Information System (GIS) (ESRI Personal Geodatabase, ArcInfo 9.2) to organize bond release data. This geodatabase was the first spatially supported database developed in Wyoming and in the USA to process reclamation bond releases. The geodatabase was designed to support the tracking of areas which have achieved specific bond release criteria and have satisfied performance standards in support of incremental bond release. Compliance features (e.g., topsoil depth, erosion, or wildlife habitat features) were monitored and entered into the geodatabase by LQD personnel during inspections using a Global Position System (GPS) enabled data collector (Trimble GeoExplorer Series GeoXM and Juno handheld GPS unit using ESRI ArcPad 7.1) (Krzyszowska Waitkus and Calle 2008). Verified field data together with information submitted by the operator were compiled into one Bond Release Geodatabase. This geodatabase is a highly effective method which sufficiently reduces the time needed to track the bond release progress and reach agreement between the operator and the regulator. It also improves the state inspector's ability to assess reclamation adequacy and progress (Krzyszowska Waitkus and Blake 2011).

\section{Summary}

The primary governmental responsibility for the regulation of surface coal mining rests with the rules and regulations of states that follow the requirements of SMCRA, 1977. The coal mine permit is an agreement between the mine operator, state, and federal agencies. The permittee is required to meet performance standards and fulfill reclamation goals to restore disturbed land to premining land use.

Coal mine permit content follows the rules and regulations of state regulatory agencies. The permit presents data requirements and collection methods to assess the adequacy of baseline and monitoring data, predicts the impacts of mining, provides information on reclamation techniques, and presents methods evaluating the success of reclamation. Because mining and reclamation schedules included in the permit are constantly changing due to market demand, the permit must be constantly updated. The schedule, permit commitments, and compliance with rules and regulations are inspected monthly by the WDEQ/ LQD's representative in the field. The permit is instrumental for the permittee and for the regulatory agencies to gather all information and present how all disturbed land can be restored to the premining land use for the western states of the USA. The presented case of the permit shows how the regulations together with the operator's experience and their best management practices are advantageous in the reclamation of severely disturbed land.

Reclamation of large surface coal mines can be successful in a disturbance-sensitive, semi-arid environment. Data from the largest surface coal mine in Wyoming shows that a disturbed area can be sufficiently revegetated to fulfill SMCRA requirements over a period of 10 years. The set of criteria and performance standards established for the state of Wyoming accelerate the bond release application submittals and more reclaimed area should be released to the land owners in timely manner. A Bond Release Geodatabase developed by the WDEQ/LQD field inspector has streamlined the bond release process and helped with compliance inspections. The GIS/GPS approach was proven to be successful for the large mining/reclamation activities of severely disturbed areas.

Open Access This article is distributed under the terms of the Creative Commons Attribution 4.0 International License (http://crea tivecommons.org/licenses/by/4.0/), which permits unrestricted use, distribution, and reproduction in any medium, provided you give appropriate credit to the original author(s) and the source, provide a link to the Creative Commons license, and indicate if changes were made. 


\section{References}

Anderson JD, Ingram LJ, Stahl PD (2008) Influence of reclamation management practices on microbial biomass carbon and soil organic carbon accumulation in semiarid mined lands of Wyoming. Appl Soil Ecol 40:387-397

Bilbrough C, Howlin S (2012) Handbook of approved sampling and statistical methods for evaluation of revegetation success on Wyoming coal mines. Wyoming Department of Environmental Quality, Land Quality Division. http://deq.wyoming.gov/lqd/ coal/resources/handbook/. Accessed 19th Feb 2017

Bonogofsky A, Jahshan A, Yu H, Cohn D, MacDonald M (2015) Undermined Promise II. National Wildlife Federation, Natural Resource Defense Council, \& Western Organization of Resource Councils. http://www.underminedpromise.org/UnderminedPro miseII.pdf. Accessed 19th Feb 2017

Bowen CK, Schuman GE, Olson RA (2005) Influence of topsoil depth on plant and soil attributes of 24-year old reclaimed mined lands. Arid Land Res Manag 19:267-284. https://doi.org/10.1080/ 15324980590951441

Buchanan B, Schuman GE, Olson RA (2005) Long-term plant community development in response to topsoil replacement depth on mined land in Wyoming. In: Barnhisel RI (ed) Raising reclamation to new heights: Proceedings of a Joint Conference of American Society of Mining and Reclamation, 22nd Annual National Conference, June 18-25, 2005, Breckenridge, Colorado, USA. ASMR, 3134 Montavesta Rd. Lexington, KY 40502, pp 108-114

Carroll C (2011) Wyoming's Coal Resources. Wyoming State Geological Survey. Summary report

Hansen BW, Murphree P (2003) Reclamation of Porcupine Creek riparian and wetland habitats. In: Barnhisel RI (ed) Working together for innovative reclamation: Proceedings of the Joint Conference of the 9th Billings Land Reclamation Symposium and the 20th Annual Meeting of the American Society of Mining and Reclamation and the 9th Billings Land Reclamation Symposium, June 3-6, 2003, Billings, Montana, USA. ASMR, 3134 Montavesta Rd. Lexington, KY 40502, pp 86-89

Ingram LJ, Schuman GE, Stahl PD, Lowell LK (2005) Microbial respiration and organic carbon indicate nutrient cycling recovery in reclaimed soils. Soil Sci Soc Am J 69:1737-1745. https://doi. org/10.2136/sssaj2004.0371

Ingram LJ, Stahl PD, Anderson JD (2007) The influence of management practices on microbial and total soil nitrogen. In: Barnishel RI (ed) 30 years of SMCRA and beyond. Proceedings of the 24th National Meeting of the American Society of Mining and Reclamation 2007: 2-6 June, Gillette, Wyoming, USA. ASMR, 3134 Montavesta Rd. Lexington, KY 40502, pp 346-360

Knight DH, Jones GP, Reiners WA, Romme WH (2014) Mountains and plains: the ecology of Wyoming. Yale University Press, New Haven

Krzyszowska Waitkus A, Blake C (2011) Tracking bond release at a large Wyoming coal mining operation. In: Barnishel RI (ed) Reclamation: science leading to success: Proceedings of the National Meeting of the American Society of Mining and Reclamation, June 11-16, 2011, Bismarck, ND, USA. ASMR, 3134 Montavesta Rd. Lexington, KY 40502, pp 338-349

Krzyszowska Waitkus A, Calle M (2008) Mobile computing and geodatabase application for coal mine inspection. In: Paper presented at the 2nd National Meeting of SMCRA Geospatial Data Stewards, March 26, 2008, OSM Geospatial Conference "Incorporating Geospatial Technologies into SMCRA Business Processes", March 25-27, Atlanta, GA

Krzyszowska Waitkus A, Smith J, Cash G, Moxley M (2000) Successful reclamation techniques and bond release for coal mine in Wyoming. In: Striving for Restoration, Fostering Technology and Policy for Reestablishing Ecological Function. Proceedings of the Billings Land Reclamation Symposium, March 20-24, 2000, Billings, Montana, USA. Reclamation Research Unit Publication No. 00-01 Montana State UniversityBozeman, pp 33-44

Norton J, Krzyszowska Waitkus A, Loubsky T (2009) Successful restoration of severely disturbed lands: overview of critical components. University of Wyoming. Cooperative Extension Service. Bulletin No. B-1202

Norton J, Krzyszowska Waitkus A, Strom C (2010) Successful restoration of severely disturbed lands: predisturbance/baseline inventory. University of Wyoming. Cooperative Extension Service. Bulletin No. B-1212

Permit 569-T8. (2014) Peabody Powder River Mining LLC, North Antelope Rochelle Mine. Wyoming Department of Environmental Quality, Land Quality Division, Cheyenne, Wyoming, USA

Pinchak BA, Schuman GE, Depuit EJ (1985) Topsoil and mulch effects on plant species and community responses of revegetated mined land. J Range Manag 38:262-265

Reynolds B, Reddy KJ (2012) Infiltration rates in reclaimed surface coal mines. Water Air Soil Pollut 223(9):5491-5958

Schroeder SA, Vinning KC (1993) Relation of compaction and soil physical parameters to productivity of reclaimed soils. Final Report. North Dakota State University Land Reclamation Research Center

Schuman GE (2002) Mined land reclamation in the Northern Great Plains: have we been successful? In: Barnishel RI, Collins M (eds) Reclamation with a purpose. Proceedings of the 19th National Meeting of the American Society of Mining and Reclamation and the 6th International Affiliation of Land Reclamationists. June 9013, 2002, Lexington, Kentucky, USA. 3134 Montavesta Rd. Lexington, KY 40502, pp 842-864

Schuman GE, Vicklund LE, Belden SE (2005) Establishing Artemisia tridentata ssp. wyomingensis on mined lands: science and economic. Arid Land Res Manag 19:353-362

Squillace M (1990) The strip mining handbook. Environmental Policy Institute. https://sites.google.com/site/stripmininghandbook/. Accessed 20th Jan 2017

State of Wyoming (2016) Wyoming Environmental Quality Act and Industrial Development Information and Siting Act. 2016 Edition, LexisNexis

Steward DGM, Burget W, Carlson R, Stowe RR, Vicklund LE (2006) Handbook of western reclamation techniques, second edition. University of Wyoming. https://www.osmre.gov/resources/ library/ghm/WestReclHandbook2ndEd.pdf. Accessed 19th Feb 2017

Strom C, Norton J, Loubsky T (2010) Successful restoration of severely disturbed lands: seeding essentials for reclaiming disturbed lands. University of Wyoming. Cooperative Extension Service. Bulletin No.B-1204

Toy TJ, Black JP (2000) Topographic reconstruction: the theory and practice. In: Barnishel RI, Darmody RG, Daniels WL (eds) Reclamation of drastically disturbed lands. Agronomy Monography 41. ASA, CSSA, and SSSA, Madison, WI, pp 41-77

USA Congress, Office of Technology Assessment (1986) Western surface mine permitting and reclamation. Washington, DC: USA Government Printing Office, June 1986, OTA-E-279. Library of Congress Catalog Card Number 86-600506

USA Government Publishing Office (2016) Chapter VII-Office of Surface Mining Reclamation and Enforcement, Department of the Interior. Code of Federal Regulations. Title 30-Mineral Resources. https://www.gpo.gov/fdsys/pkg/CFR-2016-title30vol3/pdf/CFR-2016-title30-vol3-chapVII.pdf. Accessed 18th Feb 2017 
Wick AF, Ingram LJ, Stahl PD (2009) Aggregate and organic matter dynamics in reclaimed soils as indicated by stable carbon isotopes. Soil Biol Biochem 41:201-209

Williams M, Shuman GE, Hild A, Vicklund L (2002) Wyoming big sagebrush density: effects of seeding rates and grass competition. Restor Ecol 10:385-391

Wood MK, Buchanan BA (2000) Reclamation considerations for arid regions of the southwest receiving less than twenty-five centimeters annual precipitation.. In: Barnishel RI, Darmody
RG, Daniels WL (eds) Reclamation of drastically disturbed lands. Agronomy Monography 41. ASA, CSSA, and SSSA, Madison, WI, pp 303-322

Wyoming Department of Environmental Quality (2017) Land quality division: guidelines. http://deq.wyoming.gov/lqd/resources/ guidelines/. Accessed 24th Jan 2017

Wyoming State Rules and Regulations (2017) Environmental Quality, Department of Land Quality-Coal. http://deq.wyoming.gov/ lqd/resources/guidelines/. Accessed 24th Jan 2017 